Research, part of a Special Feature on Law and Social-Ecological Resilience, Part II, Contributions from Law for SocialEcological Resilience Symposium Stockholm, Sweden, 2010

\title{
The Concept of Resilience from a Normative Perspective: Examples from Dutch Adaptation Strategies
}

\author{
$\underline{\text { Andrea M. Keessen }}{ }^{1}$ Jurrien M. Hamer $^{2}$, Helena F. M. W. Van Rijswick $^{l}$ and Mark Wiering $^{3}$
}

ABSTRACT. Both in academic literature and political practice, resilience is becoming a central evaluative concept for assessing climate adaptation policies. This makes sense because society's main challenge in an altering the environment is to adapt to the inevitable changes. However, applying the concept of resilience to devise adaptation strategies reveals that social-ecological resilience acquires different meanings depending on the social context. There is no straightforward application of resilience. In this contribution, it will be argued that giving meaning to the concept of resilience in adaptation strategies requires making normative choices. These choices concern whether there is a public interest in adaptation, the distribution of private and public responsibilities, and striking a balance between individual rights and general interests. Because these normative choices can be questioned and revised, it is important that they are made explicit to enable a democratic debate on the direction that adaptation strategies should take. Simply referring to the concept of resilience in an adaptation strategy does not suffice, but occludes this discussion. Through formulating and applying a condensed scheme of politico-theoretical approaches that underpin diverging adaptation approaches, this contribution reveals the various underlying normative assumptions and explicates the relevant political choices. Three Dutch adaptation strategies serve as empirical examples. They illustrate the importance of the societal context in giving meaning to resilience in the development of adaptation strategies.

Key Words: adaptation strategies; the Netherlands; normative choices; political theory; public interest

\section{INTRODUCTION}

Despite the uncertainty about the kind of impacts that climate change may have in particular settings, many countries are developing plans and programs to guide adaptation and to become more resilient (Biesbroek et al. 2010). Part of this adaptation process consists of making purposeful changes to governance arrangements to make them better equipped to respond to climate change (Cosens 2010, Termeer et al. 2011, Ruhl 2011). The resilience literature suggests that public actors should involve private actors in the development of adaptation strategies (e.g., Ostrom 1990, Folke 2006, Armitage 2008, Pahl-Wostl 2008, Cosens 2010, Huntjes 2011). Another emerging factor is the emphasis on marketbased regulatory mechanisms, which can entail a shift from public responsibilities for adaptation to climate change toward private responsibilities too (H. Mees, J. Dijk, D. van Soest, P. Driessen, H. Runhaar, and H. F. M. W. Van Rijswick, unpublished mansucript). These changes in the governance approach call into question the meaning of traditional and accepted normative principles that underlie contemporary governance and management practices (Driessen and Van Rijswick 2011).

Creating a policy for adaptation to climate change requires a specific meaning to be given to resilience by defining the public interest and establishing a division between public and private responsibilities for adaptation (Cohen and Arato 1994, Dubbink 2003). Whether adaptation is in the public interest and, if so, to what extent, should be made explicit to enable public debate about the direction of adaptation efforts. We provide a framework for an analysis of the plans and programs designed to make societies and their physical environments more resilient in the face of climate change, to discover which implicit or explicit justification they offer for what is in the public interest, and whether this results in different divisions of public and private responsibilities. Although the scope of this paper is largely theoretical, we will illustrate our arguments with three empirical examples from the context of three Dutch adaptation policies.

\section{THEORETICAL FRAMEWORK}

\section{The social context of resilience}

Adaptation plans generally aim to decrease vulnerability to climate change and increase resilience (Folke 2006). Resilience can thus be seen as the opposite of vulnerability (Levina and Tirpak 2006). From a normative perspective, resilience can function as a criterion to evaluate the quality of a strategy for adaptation to climate change (Adger 2006, Driessen and Van Rijswick 2011). Although resilience seems to be a straightforward concept, when applied to social systems it can either be a positive or a negative property. Resilience can reflect the ability of a system to adapt to change, but also the ability of a system to persist despite change (Gunderson and Light 2006). This ambiguity is amplified by the various meanings that adaptation to climate change can have. 
Adaptation can be directed toward offering protection against climate change, retreating in the face of climate change, or accommodating climate change through transformation.

Using the concept of resilience in a social context therefore requires answering tough questions about the direction that adaptation should take. What society do we want to preserve or to reorganize into? If resilience is about making society more resilient in the sense of being better able to cope with climate change, then how does it relate to the institutions that make society work and the principles on which these institutions are built? Is adaptation to climate change in the public interest and therefore a public task, or is it, fully or partly, a private responsibility? The concept of resilience needs to be linked to other concepts so as to reflect the social element of social-ecological resilience and to enable an explanation to be found for the various courses of action that adaptation plans can propose to increase resilience.

On the basis of several empirical studies Ebbesson (2010) identified the following elements as particularly relevant for the assessment of social-ecological resilience: (1) flexibility in social systems and institutions to deal with changes; (2) the openness of institutions so as to provide for broad participation, not least in local decision making and administration; (3) the effectiveness of multilevel governance; and (4) social structures that promote learning and adaptability without limiting the options for future development.

These are elements of adaptive management, which is generally put forward in the literature as the solution to improve social-ecological resilience (cf. Folke et al. 2005). However, adaptive management in itself does not determine the direction that adaptation policies are, or could be, taking.

Linking resilience with the concept of legitimacy reflects that adaptation efforts need strong societal support and a shared and internalized sense of urgency to become successful, i.e., to increase social-ecological resilience (Van Rijswick and Salet 2012). Legitimacy is more than openness and participation. It also includes accountability, the rule of law, fairness, equity, and, in the end, effectiveness. These elements also appear relevant in the context of adaptation to climate change (H. Mees, J. Dijk, D. van Soest, P. Driessen, H. Runhaar, and H. F. M. W. Van Rijswick, unpublished mansucript). However, what is considered legitimate differs strongly depending on the normative values to which one adheres. To determine the direction of the improvement of social-ecological resilience that adaptation policies can take, it is essential to understand on which normative values an adaptation policy can be based.

\section{Five different theories}

A key mechanism for understanding which meaning an adaptation strategy gives to social-ecological resilience is by analyzing how people define what is in the public interest and how the government should act (Alexander 2002). Societies differ in the way they conceptualize the public interest in adaptation. Different perceptions of what is in the public interest represent different ideas about what should be public or private responsibilities, which balance should be struck between individual rights and general interests, and what is found to be just. On the basis of the literature on public interest we have selected five diverging political theories: limited rights, extensive rights, utilitarian, socialist, and communitarian theory. It can be argued that far more political or legal theories could be part of the research and that focusing on these traditional approaches is not appropriate because they may not be able to deal with the governance of climate adaptation policies as a new and serious problem. It is indeed possible to extend the amount of theories, but our choice to focus on these well-known theories is that most political parties still rely on these political theories for their theoretical and normative underpinning. Although other theories may offer a more nuanced or more specific approach, they all have to deal with the same questions: how to deal with individual interests and rights and collective interests; should policies be based on an anthropocentric, an ecological, or a combined approach; should policies be based on social or economic arguments, should policies be based on a rights-based approach, or should there be room for solidarity and how to deal with the distributional effects of new policies? Because a full overview of all possible underpinning theories would be too difficult to cope with here, we have chosen to discuss the classical political theories to explain our argument. The normative guidance that these political theories offer makes preferences in adaptation strategies more explicit.

1. Limited rights theories define what is just by referring to the core freedoms of man. The ideal state guarantees that people can live in safety, but does not do much else. The rights that must be protected are negative, in that they are about what other persons and the government may not do to someone (see for an elaboration of the distinction, Berlin 1969). A just government is a modest government, a guardian of peace, not a provider of welfare. The dominant limited rights theory is libertarianism. The fundamental value of libertarianism is 'self-ownership' (Nozick 1974). It is based on respecting the spaces in which people need to lead their own lives and make their own choices (Nozick 1974, see also Kymlicka 2002). Self-ownership does not entail a positive obligation, neither for the state nor for people to help others to be autonomous. When faced with adaptation to climate change, a libertarian approach does not justify empowering the state to take large-scale measures, because social-ecological resilience means for them that citizens are able to cope themselves with environmental hazards, for instance through private insurance. Consequently, the state is not authorized to take 
adaptation action and if people have not taken out insurance, the state should not compensate their damage.

2. Extensive rights theories forcefully expand the responsibilities that governments have. Instead of negative rights, they establish numerous positive rights that governments must safeguard. The dominant extensive rights view is liberalism. The core concept of a liberal thinker is individual autonomy, i.e., all individuals must have the space and the opportunity to lead worthwhile lives (Rawls 1973, Anderson and Honneth 2005). This does not only include the protection of rights, e.g., the freedom of speech, but also the provision of adequate healthcare, good education, and a minimum of social security. Although governments have an essential obligation to support citizens, individuals still have their own responsibilities.

Liberals differentiate between choice-sensitive responsibilities and endowment-sensitive duties (Kymlicka 2002). Choice-sensitivity means that however pitiable people may be, they remain responsible for their own choices (Kymlicka 2002). Endowment sensitivity implies that unchosen circumstances that cannot be influenced must be taken into account (Dworkin 1985, Kymlicka 2002). The challenge for liberals is where to draw the line between the two. Considering adaptation to climate change, a liberal interpretation of resilience legitimates the involvement of the state to ensure that the costs and damage that result from climate change are not only borne by the people who are harmed (Farber 2007). Obviously, some people are more at risk of suffering damage from climate change than others. The pivotal question is whether they choose this risk and are therefore responsible for it themselves, or whether it is simply bad luck and therefore they deserve assistance. Liberals would consider that a public adaptation plan improves resilience if it respects private autonomy and only compensates those who deserve public assistance.

3. In contrast to these rights approaches, utilitarians seek to understand the ethical problems from a more scientific, economic perspective. According to a utilitarian, all moral claims should be measured in terms of overall utility and brought under one moral rule: actions are just when they contribute to the greatest happiness for the greatest amount of people. Importantly, utilitarians identify happiness as the experience of pleasure, and its opposite as the experience of pain (Bentham 1789, Mill 1861). Therefore, from a utilitarian perspective, there is no more and no less than an aggregation of individual interests that are objectified into an idea of the public interest. Consequently, utilitarians can accept a public adaptation plan and will find that it improves resilience if it maximizes utility. Therefore, it should be based on a cost-benefit analysis (Alexander 2002).

4. Many strands of more state-based, collectivist thought exist, ranging from Marx and Lenin to Western social democrats. Their most important claim is that capitalism, when left to its own devices, will generate an unfair society. Marx argued that because the owners of the means of production, like factories or simply capital, bought the labor of the masses, while keeping for themselves the surplus value of their toils, the laborers would end up in a position of servitude (Wood 1972). Nowadays, socialist parties still adhere to the opinion that if the government does not stringently regulate the economic market, the average person will be oppressed and exploited by the richer one. As normal interaction between private agents gives rise to exploitation, the government necessarily has to step in.

Although many varieties exist (Arneson 1994, Cohen 1999), people inspired by neo-Marxism or radical democracy as well as social democrats frequently advocate both an outcome and an opportunity type of equality (Cohen 2000). This encompassing notion of equality has led politicians to advocate a welfare state. Because the state was the institution that had both the power and the democratic legitimacy to intervene in society, it was obliged to compensate for capitalism's drawbacks. Along the lines of collectivist reasoning it is stated that solely relying on private adaptation initiatives cannot improve resilience because it will lead to inequality. They will prefer public adaptation strategies to deal with distributional effects. In their view, public action should improve resilience by ensuring equal adaptation opportunities and outcomes for all.

5. Communitarians do not take individuals and their rights as a starting point, but instead emphasize the social or communal environment of the individual. Selfdetermination, which forms the root of human rights, means little without the social environment that gives a person the possibility to make use of his or her freedom. They assume that without certain moral ideals, individuals are not capable of making good use of their freedom (Kymlicka 2002). Social structures provide someone with the values, norms, and also the practical options that allow him or her to make choices. Identity is not something that is presocially given, but something that is deeply influenced and, according to some theorists, even constituted, by the community in which one lives (Sandel 1982). Communitarian values can therefore take all kinds of forms (Kymlicka 2002). When communitarian arguments are used, the type of governmental adaptation action can assume almost any 
shape as long as it is connected to the community values. Communitarians might therefore prefer to improve resilience through private adaptation. They might also support a governmental adaptation plan if it seeks to improve resilience by protecting the 'way of life' of the community.

\section{EMPIRICAL EXAMPLES FROM THE NETHERLANDS}

Empirical research can unearth the meaning that is given to social-ecological resilience in an adaptation policy. It clarifies the underlying normative choices related to different political theories. Which political theory has informed the adaptation policy and determined the direction of adaptation can be determined empirically by analyzing: (1) on which normative values the adaptation policy is based, (2) how responsibility is divided between the state and the citizens, and (3) which instruments have been proposed.

Obviously, in a democratic society, several of the above political theories can coexist and it is possible that more than one theory has influenced an adaptation policy. A comparison with older policies that impact the same resource or area can reveal whether a shift has occurred in thinking about values, the desired involvement of the state, and individuals or the instruments that are used. Such a shift can be due to a changed political context, a changed physical context, or due to the fact that climate change is a new societal and ecological problem that asks for shifts in traditional policy approaches because of its particular characteristics. What in a certain case may be the main reason for a shift can only be concluded after extensive empirical research into adaptation measures. In this paper we make a start with this empirical research. The empirical analysis of normative choices underlying adaptation policies will take place in the context of three case studies from the Netherlands.

\section{Characteristics of the Netherlands}

The Netherlands is situated in a delta and more than half of its territory is below sea level (Fig. 1). It is a densely populated, prosperous country, especially in the part below sea level. It is extremely sensitive to the impacts of climate change because it has to deal with sea level rises, in the North Sea, and increasing water discharges from major European rivers (Van den Hurk et al. 2006). The Ems, Scheldt, Meuse, and Rhine rivers all flow through the Dutch Delta to discharge into the North Sea. It is estimated that flood risks have increased exponentially in the 20th century and will further increase in the 21st century (Ligtvoet et al. 2009, De Moel et al. 2011, Te Linde et al. 2011). As well as high water risks in winter there are also risks connected to the low discharges of rivers and low precipitation, especially during summer, leading to periods of drought that are harmful for Dutch agriculture as well as for the maintenance of river dikes (Van Duinen et al. 2011).
Fig. 1. Flood map of the Netherlands. Source: Landelijk Beheer Organisatie Risicokaart compiled by the Interprovincial Platform (IPO), Statistics Netherlands (CBS).

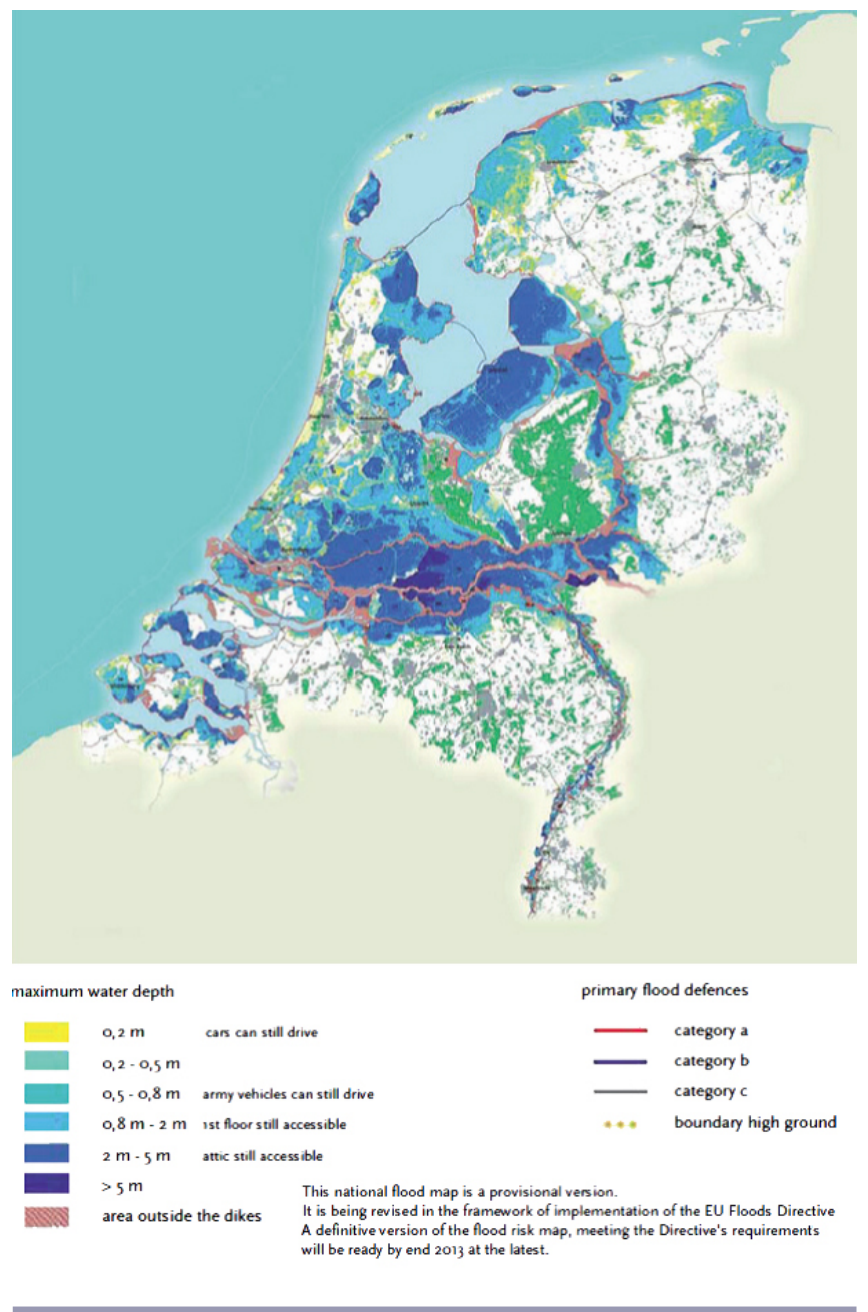

One of the most important Dutch climate adaptation plans focuses on water management. It is called the Delta Programme (based on the Dutch Water Act; see also Biesbroek et al. 2007, Veerman 2008), which discursively refers to the historical "battle against water" of former Dutch Delta plans, like the coastal zone protection plan (the famous Delta Works) and the protection against flooding from the major rivers in the 1990s (Wiering and Driessen 2001). However, climate adaptation measures need not only concern floods but also low water levels, decreasing water quality, and ecology. Adaptation in river management is in fact about river dynamics: high and low water levels, flood protection, and the quality and ecological status of flood plains. Indeed, the Delta Commission's proposed program also aims to secure a nationwide fresh water supply and explicitly establishes a link 
with the 'Space for the River' policy project, the latest, and still ongoing, major intervention in Dutch river management that deals with flood control, flood plain management, nature conservation, and the improvement of spatial values in floodprone areas.

Dutch water management is mainly divided over two layers of government: the regional water authorities, frequently referred to as 'water boards,' and the Dutch Ministry of Transport, Public Works and Water Management (Rijkswaterstaat). The regional water authorities are functional authorities that are responsible for water safety, water supply, and water quality on a subriver basin level, somewhere in between the provincial and local level. The 26 regional water authorities are organized around hydrological borders. Historically, the Dutch system of regional water management links the area-based interest that one has in good water management with the right to participate in elections or to be elected and the duty to contribute financially or personally. Financial contributions are based on the amount of land one owns or on the value of one's real estate. Electoral participation is based on a differentiated system of several types of stakeholders: inhabitants, house owners, land owners, industry, and nature conservation organizations. It is a closed and self-supporting system; those whose interests are at stake can elect or be elected in the representative bodies of the water board and make the decisions, but they also pay for the water management measures in their area (Van Rijswick and Havekes 2012).

This relationship of 'stake, say and pay' created a shared longterm responsibility and encouraged sustainable behavior. One could say that the Dutch water authorities originate from a communitarian need for collective measures regulating safety and supply and they evolved into state-based organizations, though still operating relatively autonomously. This closed system does not exist at the national level. The national water agency (Rijkswaterstaat) manages the major rivers and small parts of the coastal flood prevention measures as well as the main infrastructure for fresh water supply. The national water management measures are paid for by all taxpayers and not only by those who profit from them (Van Rijswick and Havekes 2012).

Because the major rivers cross the Dutch borders, one would expect that the transboundary element would be taken strongly into account in the national adaptation plan. Indeed, a transboundary approach is implied in the river basin management approach put forward by the European Water Framework Directive (EU 2000) and the European Floods Directive (EU 2007). Although the plans for the river basins should be coordinated to improve coherence, each member state is only responsible for compliance with the directives in its own part of the river basin. Add to this the soft legal obligations that best characterize transboundary cooperation under these directives (Keessen et al. 2008), then the lack of attention to the transboundary dimension of adaptation becomes understandable. Perhaps a legal framework for adaptation at the EU level will raise the transboundary dimension of adaptation, but currently adaptation has a strong domestic focus in the Netherlands (Termeer et al. 2011).

\section{The public interest in protection against flooding}

Dutch flood control is first and foremost a public concern managed solely by Dutch governmental bodies (Van Rijswick and Havekes 2012). Since the 19th century, water management has been modernized by technical interventions in water infrastructure (Van der Ven 1993, Van der Woud 2006). Market players do not have a role in flood management and both civil society and the general public are merely involved through their democratic rights to elect Members of Parliament to control the national water agency, and the board of their regional water authority. The state and the regional water authorities care for Dutch citizens 'by keeping their feet dry. ' Flood control is a governmental responsibility that every political party seems to agree upon, either motivated by reasons of security, solidarity, or the protection of communities. As the popular Dutch saying goes, there are no left-wing or right-wing dikes.

This approach is reflected in safety standards that are uniformly set for specific regions, distinguishing the high-risk Western part from other, lower risk parts of the country, and established by law, to which Dutch primary flood defences must conform. Nonconformity makes the state or the water board liable for flood damage (Gilissen and Schueler 2012, Van Rijswick and Havekes 2012). These safety standards are among the most ambitious in the world (Aerts et al. 2008). The high-risk western part of the country is protected against flooding by dikes. The legal safety norm that applies to these dikes is that they should be high enough to protect against water levels expected to occur once every 10,000 years (Ministry of Transport, Public Works and Water Management 2009). After the near disastrous events of 1993 and 1995, when the Rhine and Meuse Rivers reached extreme and unexpected high levels of water, and the Netherlands just escaped largescale flooding, the first reflex response was to strengthen the dikes to ensure that the safety standards were met (Aerts and Droogers 2004). The second response, however, was to actually reconsider the prevailing risk strategy. The desirability of an approach that was predominantly focused on the prevention of floods and not on the potential consequences of flooding, including flood preparedness, was now being publicly discussed.

The physical changes sparked a discussion that caused the national water agency and the regional water authorities to open up their decision making processes and become more transparent on the rationales for flood safety strategies. This increased the discursive space for a more nature friendly and 
spatially relevant policy project called Space for the River, which was carried out in the following years (Ministry of Transport, Public Works and Water Management 2006). It also gave way to a discussion about market-based policy instruments in Dutch flood policy, in particular whether insurance could complement governmental responsibilities (Aerts and Botzen 2011). Moving in the direction of a different approach to flood risks implied that the discourse of the water experts had to evolve from a "battle against water" storyline, which went hand in hand with reducing flood probabilities and relying on technical flood defence measures, toward the acceptance of possible flood occurrences and consequences and investigating measures to reduce these consequences and to shift part of the responsibility to private parties (Immink 2007, Meijerink and Dicke 2008) and other governmental authorities, such as municipalities.

At first, new approaches were predominantly framed in the discussion as flood risk strategies in themselves and not as adaptation to climate change strategies. Only after Hurricane Katrina and $\mathrm{Al}$ Gore's apocalyptic message in "An Inconvenient Truth," in which the Netherlands was visualized as one of the poor deluged countries, did climate change and adaptation become a societal and politically salient issue (Ligtvoet et al. 2009). Flood safety used to be considered a public concern by all political philosophies for protection for all, for cost-benefit or security reasons. However, the potential increase of flood risks in the context of climate change adaptation has led to a renewed discussion of flood risk management. As part of the debate on the national adaptation policy, various strategies to adapt to future extremes are being considered (Kabat et al. 2005): (1) proceed with building ever higher and larger dikes, but now build climate-proof dikes; (2) create a multilayered strategy, which includes flood defence but also flood preparation measures and evacuation plans; and (3) proceed with 'Space for the River' measures, which integrate nature conservation, land use planning, and water management.

Essentially, a choice has to be made between the traditional approach to flood prevention by endlessly heightening dikes and new approaches to flood risk management, which are not only based on flood probabilities but also on flood consequences (Aerts et al. 2008). Introducing a multilayered strategy results in a more encompassing risk-oriented flood strategy, in line with the European Floods Directive (EU 2007). It would expand the range of measures from flood defence by building dikes to spatial development and building flood mitigation measures, flood preparation, and flood response (Government of The Netherlands 2009) and also expand the range of competent authorities within provinces and municipalities. It would thus end the closed financing system and shift to a system based on general taxes by making flood protection one of the many public tasks to be dealt with by national and local governments. This choice cannot be made by solely referring to the principle of resilience. Each scenario could improve social-ecological resilience. The question is what sort of resilient society the Dutch want to create. This is where our theoretical framework provides an explanation.

Limited rights proponents might support the decision to build ever higher dikes, because dikes provide safety. However, they would loath paying higher taxes to allow the competent water authorities or other governments to secure enormous dikes if other scenarios of shared responsibility are possible and they therefore prefer a multilayered strategy. From a liberal point of view, the high costs of technical adaptation measures are problematic in so far as no difference is made between people who choose to live in certain riskier areas, and those who expressly avoid such a risk by taking out insurance (if available), building safer houses, or moving to another, safer region. They would consider it fair to allow those who want to live in dangerous places to take responsibility for protecting themselves. Therefore, they would opt for the multilayered strategy and propose the financing of dikes from local budgets.

From a utilitarian perspective, it is important to consider whether it is cost-effective to heighten the dikes considering the potential consequences of a flood occurrence. They would certainly want to investigate the cost-effectiveness of a multilayered strategy and the Space for the River Strategy. From a more state-based and collectivist perspective, flood protection should remain a state responsibility. They would oppose a multilayered strategy in so far as it negatively affects vulnerable groups, who are more likely to live in flood-prone areas but lack the finances to relocate or to pay for flood insurance. Communitarian thinkers are divided. Environmental communitarians would opt for the Space for the River policy to improve the ecological richness of river basins, whereas coastal or riverine communitarians may prefer maintaining the status quo and hence the dikes. Some communities may feel threatened by the changes in land use caused by the Space for the River policy and feel unprepared to deal with floods as required under a multilayered strategy. Because both liberal and more collectivistic proponents acknowledge and support the important role of government in securing people from flood risks, preventive measures continue to occupy center stage in Dutch flood risk strategies although other options are taken in consideration as well (www.deltacommissaris.nl/english/).

\section{The public interest in fresh water supply}

The current Dutch approach to water scarcity is based on the legal notion that water is a public good, which can be freely used in times of abundance but is publicly managed in times of drought (Van Rijswick and Havekes 2012). In the Netherlands, the responsibility of supplying fresh water is considered to be a public task and until today the government has provided all fresh water users, as much as possible, with 
enough water for their specific needs such as drinking water, water for agriculture, and cooling water for industry and energy. The national government takes care of the fresh water supply of the greater rivers and lakes, and regional water authorities manage all other waters. The government then uses water infrastructure works to transfer river water from one area to another in accordance with water agreements between these areas and it regulates the water use of the various functions such as drinking water and navigation.

The government has established a water use hierarchy by law to distribute water in times of water scarcity (Ministry of Transport, Public Works and Water Management 2009). Water safety, i.e., the stability of flood defenses, and the prevention of irreversible harm to nature come first, drinking water and energy supply come second, followed by high value use, such as the temporary irrigation of capital intensive crops and industrial process water. The fourth category comprises shipping, agriculture, nature (in the absence of irreversible damage), industry, water recreation, and inland fisheries and other interests (Van Rijswick and Havekes 2012). Tradable water rights or a market-based approach have never existed because a fresh water supply has only rarely been a problem (Van Rijswick and Havekes 2012). Indeed, the traditional Dutch approach is to use pumping stations to direct water quickly toward the sea to enable living and farming on lowlying land. However, climate change, with its forecast droughts and sea level rises, forces the Dutch to consider fresh water supply as a new problem in water management.

The Delta Programme Committee is discussing whether the current way of dealing with water scarcity should persist or if a new way of dealing with this issue should be developed. The challenge is finding a just balance between public and private responsibility. Currently the adaptation approach is being developed for the next few decades, explicitly paying attention to the question of what public interest is at stake and what the role of public and private parties in the future should be. At the same time though, several innovative initiatives are experimenting with new ways to deal with water scarcity as a climate-related problem. Local water storage areas, which are also useful in times of flooding, can be used to store water for periods of drought. Traditionally, regional water authorities construct and manage water storage areas for flood management. At the moment, private parties are developing water storage to prevent damage from drought. It is particularly interesting for farmers because their water use has a low priority in the public water hierarchy that is used to distribute water in times of drought (Van Rijswick and Havekes 2012). The idea is to use private land for storing water in times of abundance. The owner of the stored water can then use it, sell it, or share it within a cooperative in times of drought.

The experiments clearly show a shift in water scarcity and drought management from a more communitarian and collectivist (state-based) approach toward a liberal approach. As stated above, socialist thinking would never allow a fundamental resource such as water to be subjected to market forces, while a libertarian would consider it a good thing, being independent of environmental concerns. Again, the liberal position chose a middle ground between these two extremes, allowing the government to regulate the water market to safeguard everyone's basic water rights. However, it is communitarian thinking that sparked this shift. Local farming communities usually profit from the current arrangement because they have the necessary water resources available, but they are worst hit by droughts because of their low position in the public water hierarchy system. Consequently, they act on the perception that droughts will occur more frequently, which challenges the current legal system. The choice to focus more on a liberal and even libertarian solution should be the result of an explicit democratic process, and should not be the sole implication of a more resilient adaptation strategy. The same holds true for taking an economic approach to the scarcity of water resources. If experiments with the privatization of certain water resources turn out to be more cost-effective than maintaining the traditional public approach, this does not mean that the question concerning privatization is answered. A costbenefit analysis points to a utilitarian normative framework, which is only one among many. It is typical that while the Delta Programme Committee is debating which direction should be taken, in practice initiatives have already been developed. Again, taking crucial decisions on scarcity and drought management should not happen implicitly, but explicitly, with reference to the value orientations described above.

\section{Balancing the public interest in flood protection with fresh water supply and ecosystem protection}

In 1953 the Dutch province of Zeeland was confronted with a major sea storm surge, with over 1800 lives lost. The storm surge peak coincided with the spring high water tide in the North Sea and left the Dutch with a national trauma that still determines the attitude of the people from Zeeland toward water management and flood protection. After the flooding, the concern for safety led to the development of the Delta Works. The Delta Works cut the delta of Zeeland almost completely off from the sea. The Haringvliet Dam was completed in 1970. It offers safety to the inhabitants of the area and at the same time benefits agriculture by creating a freshwater reservoir and additional land for agricultural use. However, it also meant that the natural estuarian dynamic of the Rhine was lost, which led to a thorough change of the river landscape, caused the death of many organisms, and seriously hindered fish migration. Moreover, the dam resulted in pollution of the riverbed and poor chemical and ecological status of the water.

These negative environmental consequences led the Dutch government in close cooperation with other countries sharing 
the river basin of the Rhine and the Meuse to propose opening the dam to improve the ecological quality of the estuary without reducing flood safety. From the beginning, the socalled 'Crack decision,' which refers to the temporary opening of the Haringvliet Dam, led to resistance in the region. Regional parties, in particular water boards and municipalities, pointed to the enormous uncertainty of the development of the ecological values of the river, the difficulty in managing the salt intrusion, the uncertain consequences for navigation, and the uncertain consequences of a fluctuating water level. Private parties were concerned about their fresh water supply, in particular farmers ${ }^{[1]}$ and the publicly owned drinking water companies. Their criticism and the uncertainty led to the decision to only slightly open the locks at high tides. This was not sufficient to restore the estuary and improve its ecological status. Fish migration would however improve.

Despite this careful approach, regional parties remained skeptical. They questioned the independence of the environmental impact assessment and various parties wanted additional research to be carried out. Finally, the Crack decision was taken in $2000 .{ }^{[2]}$ It projected that the locks of the Haringvliet Dam would slightly open at high tides in 2005. In addition, a link was established with the Delta nature project, which aimed to gain 3000 hectares of new wetlands in the Delta. Further measures to improve the ecological status would only be taken with a careful step-by-step approach, which offers the opportunity to take better informed decisions and to deal with uncertainty and changing circumstances. An important precondition for the operationalization of the Crack decision was that compensatory measures would be taken to guarantee fresh water supply. This should take place through alternative fresh water supply canals, which would however reduce agricultural land use. These measures proved so controversial that they, and hence the Crack decision, could not be executed.

The regional resistance led to a postponement until 2008 and then to a further postponement to December 2010. The postponement severed the link between the Crack decision and the Delta Nature project, to the detriment of the ambition to create integrated spatial development. After the formation of a right-wing and communitarian government in September 2010, it seemed that the postponements would end in abandoning the whole decision. However, the proposed withdrawal of the Crack decision had serious legal and diplomatic consequences because the Netherlands had committed itself in the coordinated international river basin management plans for the rivers Rhine and Meuse to implement the Crack decision. The other riparian states were expecting the implementation of the decision to improve fish migration. After strong pressure from the European Commission and the international river basin members and because of formal obligations following from international and European environmental law as well as a lack of proper alternatives to improve ecological status or fish migration, it seems that compensatory measures will be realized and the locks will finally be opened.

The case of the Haringvliet locks shows a conflict between a variety of interests. The conflict between flood safety and the creation of resilient ecosystems, including fish migration, can be significantly reduced through opening the Haringvliet locks. However, opening the locks creates a conflict between the ecological requirements and the fresh water supply for agriculture, industry, and drinking water companies, which is not so easy to solve. According to our framework, there are quite a number of options. On the one hand, from a communitarian and libertarian perspective, the government should try to reconcile ecosystem protection with the interests of the farming communities. For a traditional communitarian, the farmers' way of life in this area must simply remain possible, while the libertarian immediately rejects attempts to favor nature over private property.

On the other hand, opening the locks may be defended from a liberal and utilitarian perspective. Liberals may prefer to open the locks in view of international commitments and advocate some form of compensation. They would not agree with the demanding plan of guaranteeing farmers their current share of fresh water. From a utilitarian perspective, the return of proper fish migration will benefit fishermen and people who like to see nature being restored, and affects numerous economic interests on an international scale. This could outrank local farmers' interest in fresh water. Moreover, the more idealistic environmentalist form of communitarianism backs opening the locks because it underlines the independent importance of ecological biodiversity in a community and attributes independent value to the restoration of the natural ecological system. In the end, the government chose to open the locks, favoring the latter perspectives over the former. However, more than the other examples, this example not only showed the conflict of the underlying normative positions, but also exhibited an actual political struggle between different interests and visions. Although such a struggle is important, it has to be noted that an open discussion only occurred at a late stage and was strongly influenced by the European and transboundary dimension of the issue. This is disappointing, because fundamental discussions about different political views should be held before decisions are taken.

\section{DISCUSSION}

The three cases analyzed show that long-standing practices in the Netherlands are put to the test when both projected and real climate changes have to be taken into account. Adaptation policies, which frequently conflict with old policies, are being proposed. They indicate a shift in the normative framework that determines what actions are in the public interest. This change is significant because flood defence and water management have been a public responsibility in the 
Netherlands since the 19th century. Several adaptation strategies question this choice as they seek to complement the dominant state-based preventive approach with other approaches, which focus more on preparedness and damage control and rely more on private initiatives, including private insurance. Additionally, although fresh water supply and the improvement of the resilience of ecological systems have been recognized as being in the public interest, they are the subject of controversy because these tasks easily provoke conflicts with other interests such as economic development and, in the case of ecology, agriculture.

The general shift in perspective can be framed in two ways. First, there is the division between the public and private societal domain, and the responsibilities that belong to each of these spheres. As discussed, a libertarian perspective shows a limited view of responsibility in the public, governmental sphere, whereas a more collectivist approach entertains the opposite opinion. Both in the first case, on new ways to deal with the threat of flooding, and in the second case, on managing the water supply, this distinction is highly informative. The second shift relates to the definition of the public interest and its relation with individual rights. Whereas some political theories, such as liberalism, solely think in terms of rights, communitarian and utilitarian thought are much more concerned with the interest for the whole of society, seen as a single entity. In the Haringvliet locks case, it became clear how difficult it is to resolve a dispute in a situation in which parties refer to different normative backgrounds. For how do you convince someone who reasons according to his rights or way of life of the need to preserve ecological biodiversity?

As to the division between public and private societal domains, the consensus over Dutch water management as a predominant public responsibility is lost and the government in charge in 2012 seemed to at least consider shifting toward a more liberal or even libertarian position as it strives to improve resilience in the face of climate change. The long held saying that water management is not a political issue may no longer be true. Different political views regarding the division of public and private responsibilities are not only visible with regard to flood defence, but also with regard to the use of fresh water for agriculture. Because agricultural water use has a low ranking in the publicly established water hierarchy that applies in times of drought, dry periods have sparked among farmers a willingness to be responsible for their own water use. Many farmers participate in experiments to improve their resilience to drought through private water storage.

The experimental development of private water storage shows that if water shortage becomes a more structural phenomenon in the Netherlands because of climate change, it can trigger a shift from public to private responsibilities unless stakeholders can count on the government to take care of the fresh water supply. The adaptation discussion has not dramatically altered the consensus regarding flood safety, which is shared by all political theories from libertarians to socialists. However, the space for the river project reveals that even here the consensus is cracking. It would probably take a serious flood to completely alter this situation. Nevertheless, it can be safely concluded that the direction taken in adaptation strategies to increase resilience entails a political choice because the alternatives to classic Dutch water management solutions do not equally appeal to every political theory. As we have seen, other methods of land use and water supply easily come into conflict with the normative values and established rights of communities. To give another example, although insurance is appealing from a liberal and libertarian perspective, it is not from a socialist perspective for fear that those who are too poor to pay for insurance will not be compensated for damage.

Considering the second aspect, the relation between the collective public interest and individual rights shifts with regard to the importance given to nature conservation and ecological improvement can definitely be witnessed. These shifts could be due to contemporary neo-liberal tendencies in the Dutch government and politics. Since the middle of the last century the government started to take care of nature conservation and ecology, and over the years public responsibility has intensified. However, a case such as the Haringvliet locks debacle reveals that this new attitude could be in swift decline. When the farming community protested, their rights to property and their livelihood temporarily superseded the interests of restoring fish migration and providing ecological and economic benefits for the much larger European river basins. Indeed, a positive aspect of the Haringvliet locks case was that ideas and values were made explicit because of the protests. This shows the different meanings that resilience can acquire in adaptation strategies and how crucial it is to deal with these differences in order to realize a legitimate and resilient strategy.

\section{CONCLUSIONS}

Although adaptation policies generally aim to decrease vulnerability and increase resilience, their content can differ significantly. Obviously, there are no 'one size fits all' solutions, but just referring to the increasing resilience as a reason for an adaptation strategy does not explain which meaning is given to resilience in a particular social context. Charting the normative value orientations that underlie an adaptation strategy makes this explicit. Looking at the Dutch adaptation strategies, it is clear that climate change has sparked new and different thinking, which implicitly questions the old normative structure of seeing water management as a public, governmental responsibility. This stresses the point that thinking about increasing social-ecological resilience in the face of climate change implies thinking about what sort of society one wants to make resilient. How important are the rights of people threatened by flooding? How should one 
distribute water in times of drought? How should a concern for ecological values be represented in decision making procedures? These questions have to be answered in a democratically, transparent and participatory way, before adaptation policies can focus on realizing resilient solutions that can count on broad societal support.

Therefore, focusing on transparent and legitimate decision making in the development of adaptation strategies is of paramount importance. Sadly, the examples set in the Dutch case studies do not bode well. New and challenging ideas and reinterpretations of the interests involved in adaptation were rarely accompanied by conscious decisions and transparent visions that explain the underlying shifting normative values. In this contribution, we have attempted to clarify normative values that determine the meaning people assign to increasing resilience to broaden the discussion about resilience, and to place the concept of resilience in a social context. Although the Dutch cases showed an implicit change in politics and normative viewpoints, many of the traditional values are still safeguarded. For example, in flood management new, more utilitarian and liberal approaches have not yet resulted in the abandonment of the old safety standards although they are under discussion. Flood management is still one of the most important and broadly accepted public tasks. Consciously or not, the existing institutional water management structures, in the form of the regional water authorities, are defending the existing preventive approach, including the traditional value of high safety standards, which are based on consensus surrounding the values of security and protection for all against flooding.

Considering the need to increase resilience in the face of climate change, the challenge is to develop a correct and fair mix between public and private responsibilities, without necessarily losing the valuable elements of present Dutch water management. On the basis of the empirical cases, we can stress the reliance on solidarity, the keen eye for (technical) prevention, the functional specialization of water agencies, and the strong involvement of stakeholders as strong ingredients of a resilient strategy. If increasing societal resilience warrants a shift from public toward private responsibilities, public debate should follow concerning the changing role of government and what kind of adaptation policy it defines as being in the public interest. Without this, specific private parties, but also the public at large, do not become fully aware of this shift and will be confronted with responsibilities they are not willing or even able to accept. In the end that will lead to a lack of legitimacy surrounding adaptation policies and not to the desired improvement of social-ecological resilience.

${ }^{[1]}$ They own $80 \%$ of the land, employ $8.8 \%$ of the population of Zeeland, and produce 3\% to $7 \%$ added value depending on whether their own produce or the entire chain is included in the calculation. See: http://www.zeeland.nl/index?lng=en.
[2] Besluit Beheer Haringvlietsluizen, 5 June 2000 Staatscourant. 9 June 2000, 110.

Responses to this article can be read online at: http://www.ecologyandsociety.org/issues/responses. php/5526

\section{Acknowledgments:}

This paper is written as a part of the research project Governance of Adaptation to Climate Change, which is funded by the Dutch research programme Knowledge for Climate. This publication is also written as part of the project 'Modular legal formats for hybrid institutions protecting public values in water management,' which is supported by the Next Generations Infrastructures Foundation (www. nextgenerationinfrastructures.eu).

\section{LITERATURE CITED}

Adger, W. N. 2006. Vulnerability. Global Environmental Change 16:268-281.

Aerts, J. C. J. H., and W. J. W. Botzen. 2011. Climate change impacts on pricing long-term flood insurance: a comprehensive study for the Netherlands. Global Environmental Change 21(3):1045-1060. http://dx.doi. org/10.1016/j.gloenvcha.2011.04.005

Aerts, J. C. J. H., W. J. W. Botzen, A. van der Veen, J. Krywkow, and S. Werners. 2008. Dealing with uncertainty in flood management through diversification. Ecology and Society 13(1): 41. [online] URL: http://www.ecologyandsociety. org/vol13/iss1/art41/

Aerts, J. C. J. H., and P. Droogers. 2004. Climate change in contrasting river basins: adaptation strategies for water, food and environment. CABI, London, UK. http://dx.doi. org/10.1079/9780851998350.0000

Alexander, E. R. 2002. The public interest in planning: from legitimation to substantive plan evaluation. Planning Theory 1(3):226-249. http://dx.doi.org/10.1177/147309520200100303

Anderson, J., and A. Honneth. 2005. Autonomy, vulnerability, recognition, and justice. Pages 127-149 in J. Christman and J. Anderson, editors. 2005. Autonomy and the challenges to liberalism. Cambridge University Press, Cambridge, UK. http://dx.doi.org/10.1017/CBO9780511610325.008

Armitage, D. 2008. Governance and the commons in a multilevel world. International Journal of the Commons 2(1):7-32.

Arneson, R. J. 1994. What do socialists want? Politics and Society 22(4):549-567. http://dx.doi.org/10.1177/00323292$\underline{94022004009}$ 
Bentham, J. 1789. An introduction to the principles of morals and legislation. T. Payne and Son, London, UK.

Berlin, I. 1969. Two concepts of liberty. In I. Berlin. Four essays on liberty. Oxford University Press, London, UK.

Biesbroek, G. R., R. J. Swart, T. R. Carter, C. Cowan, T. Henrichs, H. Mela, M. D. Morecroft, and D. Rey. 2010. Europe adapts to climate change: comparing national adaptation strategies. Global Environmental Change 20:440-450. http:// dx.doi.org/10.1016/j.gloenvcha.2010.03.005

Cohen, G. A. 1999. Marxism after the collapse of the Soviet Union. Journal of Ethics 3(2):99-104. http://dx.doi. org/10.1023/A:1009825115756

Cohen, G. A. 2000. If you're an egalitarian, how come you're so rich? Journal of Ethics 4:1-26. http://dx.doi.org/10.1023/ A:1009836317343

Cohen, J. L., and A. Arato. 1994. Civil society and political theory. MIT Press, Cambridge, Massachusetts, USA.

Cosens, B. 2010. Transboundary river governance in the face of uncertainty: resilience theory and the Columbia River Treaty. Journal of Land, Resources \& Environmental Law 30 (2):229-265.

De Moel, H., J. C. J. H. Aerts, and E. Koomen. 2011. Development of flood exposure in the Netherlands during the 20th and 21st century. Global Environmental Change 21 (2):620-627. http://dx.doi.org/10.1016/j.gloenvcha.2010.12.005

Driessen, P., and H. F. M. W. Van Rijswick. 2011. Normative aspects of climate adaptation policies. Climate Law 2:559-581.

Dubbink, W. 2003. Assisting the invisible hand: contested relations between market, state and civil society. Kluwer Academic, Dordrecht, The Netherlands. http://dx.doi. org/10.1007/978-94-017-0797-8

Dworkin, R. 1985. A matter of principle. Harvard University Press, London, UK.

Ebbesson, J. 2010. The rule of law in governance of complex socio-ecological changes. Global Environmental Change 20:414-422. http://dx.doi.org/10.1016/j.gloenvcha.2009.10.009

European Union (EU). 2000. Directive 2000/60/EC of the European Parliament and of the Council of 23 October 2000 establishing a framework for community action in the field of water policy. EU, Brussels, Belgium.

European Union (EU). 2007. Directive 2007/60/EC of the European Parliament and of the Council of 23 October 2007 on the assessment and management of flood risks. EU, Brussels, Belgium.
Farber, D. 2007. Adapting to climate change: who should pay? UC Berkeley Public Law and Legal Theory Research Paper Series Paper No. 980361. [online] URL: http://papers.ssrn. com/sol3/papers.cfm?abstract_id=980361

Fischhendler, I., and T. Heikkila. 2010. Does integrated water resources management support institutional change? The case of water policy reform in Israel. Ecology and Society 15(1): 4. [online] URL: http://www.ecologyandsociety.org/vol15/ iss $1 / \operatorname{art} 4 /$

Folke, C. 2006. Resilience: the emergence of a perspective for social-ecological systems analyses. Global Environmental Change 16:253-267. http://dx.doi.org/10.1016/j. gloenvcha.2006.04.002

Folke, C., T. Hahn, P. Olsson, J. Norberg. 2005. Adaptive governance of social-ecological systems. Annual Review of Environment and Resources 30:441-473. http://dx.doi. org/10.1146/annurev.energy.30.050504.144511

Gilissen, H. K, and B. J. Schueler. 2012. De invloed van dreigende overheidsaansprakelijkheid op adaptatie aan klimaatverandering in het Nederlands regionale watersysteembeheer. Pages 145-192 in N.Teesing, editor. Vereniging voor Milieurecht, Naar aansprakelijkheid voor (de gevolgen van) klimaatverandering? Boom Juridische uitgevers, Den Haag, The Netherlands.

Government of The Netherlands. 2009. National Waterplan 2009-2015. Government of The Netherlands, The Hague, The Netherlands. [online] URL: http://www.rijksoverheid.nl/ documenten-en-publicaties/rapporten/2009/12/01/nationaalwaterplan-2009-2015.html

Gunderson, L., and S. S. Light. 2006. Adaptive management and adaptive governance in the Everglades ecosystem. Policy Sciences 39:323-334. http://dx.doi.org/10.1007/s11077-006-9027-2

Huntjes, P. 2011. Water management and water governance in a changing climate, experiences and insights on climate change adaptation in Europe, Africa, Asia and Australia.. Eburon, Delft, The Netherlands.

Immink, I. 2007. Voorbij de risiconorm; nieuwe relaties tussen ruimte, water en risico. Dissertation. Wageningen University and Research Centre, Wageningen, The Netherlands.

Kabat, P., W. van Vierssen, J. A. Veraart, P. Vellinga, and J. Aerts. 2005. Climate proofing the Netherlands. Nature 438:283-284 http://dx.doi.org/10.1038/438283a

Keessen, A. M., J. J. H. van Kempen, H. F. M. W. Van Rijswick. 2008. Transnational river basin management in Europe. Utrecht Law Review (4)3:35-56. [online] URL: http:// www.utrechtlawreview.org/index.php/ulr/article/view/83/83 
Kymlicka, W. 2002. Contemporary political philosophy: an introduction. Oxford University Press, New York, New York, USA.

Levina, E., and D. Tirpak. 2006. Adaptation to climate change: key terms. Organisation for Economic Co-operation and Development, Paris, France.

Ligtvoet, W., J. Knoop, B. Strengers, and A. Bouwman. 2009. Flood protection in the Netherlands: framing long-term challenges and options for a climate-resilient delta. Publication number 500078004, Netherlands Environmental Assessment Agency (PBL), Bilthoven, The Netherlands.

Meijerink, S., and W. Dicke. 2008. Shifts in the public-private divide in flood management. International Journal of Water Resources Development 24(4):499-512. http://dx.doi. org/10.1080/07900620801921363

Mill, J. S. 1861. Utilitarianism. Fraser's Magazine for Town and Country, London, UK.

Ministry of Transport, Public Works and Water Management. 2006. Spatial planning key decision 'room for the river': investing in the safety and vitality of the Dutch river basin region. Ministry of Transport, Public Works and Water Management, Utrecht, The Netherlands.

Ministry of Transport, Public Works and Water Management. 2009. Water act. Ministry of Transport, Public Works and Water Management, Utrecht, The Netherlands.

Nozick, R. 1974. Anarchy, state, utopia. Basic Books, New York, New York, USA.

Ostrom, E. 1990. Governing the commons: the evolution of institutions for collective action. Cambridge University Press, Cambridge, UK. http://dx.doi.org/10.1017/CBO9780511807763

Pahl-Wostl, C. 2008. Requirements for adaptive water management. Pages 1-22 in C. Pahl-Wost, P. Kabat, and J. Möltgen, editors. Adaptive and integrated water management: coping with complexity and uncertainty. Springer-Verlag Berlin, Heidelberg, Germany. http://dx.doi.org/10.1007/978-3-540-75941-6 1

Rawls, J. 1973. A theory of justice. Harvard University Press, Cambridge, Massachusetts, USA.

Ruhl, J. B. 2011. General design principles for resilience and adaptive capacity in legal systems - with applications to climate change adaptation. North Carolina Law Review 89:1373-1401.

Sandel, M. 1982. Liberalism and the limits of justice. Cambridge University Press, Cambridge, UK.

Te Linde, A. H., P. Bubeck, J. E. C. Dekkers, H. de Moel, and J. C. J. H. Aerts. 2011. Future flood risk estimates along the river Rhine. Natural Hazards and Earth System Sciences 11 (2):459-473. [online] URL: http://hdl.handle.net/1871/33046 http://dx.doi.org/10.5194/nhess-11-459-2011

Termeer, C. J. A. M., A. R. P. J. Dewulf, H. F. M. W. Van Rijswick, M. W. van Buuren, D. Huitema, S. Meijerink, T. Rayner, and M. A. Wiering. 2011. The regional governance of climate adaptation: a framework for developing legitimate, effective and resilient governance arrangements. Climate Law $1: 1-21$

Van den Hurk, B., A. Klein Tank, G. Lenderink, A. van Ulden, G. J. van Oldenborgh, C. Katsman, H. van den Brink, F. Keller, J. Bessembinder, G. Burgers, G. Komen, W. Hazeleger, and S. Drijfhout. 2006. KNMI climate change scenarios 2006 for the Netherlands. Report WR 2006-01. Koninklijke Nederlands Meteorologisch Instituut (KNMI), De Bilt, The Netherlands. [online] URL: http://www.knmi.nl//klimaatscenarios/ knmi06/WR23mei2006.pdf

Van der Ven, G. P. 1993. Man-made lowlands, history of water management and land reclamation in the Netherlands. Uitgeverij Matrijs, Utrecht, The Netherlands.

Van der Woud, A. 2006. Een nieuwe wereld: Het ontstaan van het moderne Nederland. Bert Bakker, Amsterdam, The Netherlands.

Van Duinen, R., T. Filatova, and A. van der Veen. 2011. Understanding farmers' drought risk adaptation in the Netherlands. IGS-SENSE Conference: Resilient societies governing risk and vulnerability for water, energy and climate change. University of Twente, Enschede, The Netherlands.

Van Rijswick, H. F. M. W., and H. J. M. Havekes. 2012. European and Dutch water law. Europa Law Publishing, Groningen, The Netherlands.

Van Rijswick, M., and W. Salet. 2012. Enabling the contextualization of legal rules in responsive strategies to climate change. Ecology and Society 17(2): 18. http://dx.doi. org/10.5751/ES-04895-170218

Veerman, C. 2008. Samen werken met water. Een land dat leeft, bouwt aan zijn toekomst. Bevindingen van de Deltacommissie 2008. Deltacommissie, The Hague, The Netherlands. [online] URL: http://www.deltacommissie.com/ doc/2008-09-03\%20Advies\%20Deltacommissie.pdf

Wiering, M. A., and P. P. J. Driessen. 2001. Beyond the art of diking: interactive policy on river management in the Netherlands. Water policy 3(4):283-296. http://dx.doi. org/10.1016/S1366-7017(01)00075-7

Wood, A. 1972. The Marxian critique of justice. Philosophy of Public Affairs 1(3):244-282. 